\title{
Application of lodized In Farm and Haloferax Bacteria Technology for Salt Production in Order to Make Zero Waste Salt Consumption Industry
}

\author{
Nilawati ${ }^{1, *}$, Rizal Awaludin Malik ${ }^{1}$, Rame $^{1}$, and Yose Andriani ${ }^{1}$ \\ ${ }^{1}$ Center for Industrial Pollution Prevention Technology, Industrial Research and Development Agency, Ministry of Industry, Jl. Ki \\ Mangunsarkoro No. 6 Semarang - Indonesia
}

\begin{abstract}
The consumption salt industry produces wastewater in the raw material washing unit. The washing water generated if water concentration already exceeds $250 \mathrm{Be}$, most of its water removed, usually dumped into the environment around the factory, with a volume of about $1.5 \mathrm{~m} 3$ per 10 tons of salt washed. Everyday industry wash 60-70 tons salt. So the environment would pollute, because there were metals and chemical contaminants, such as $\mathrm{MgSO} 4, \mathrm{MgCl} 2$, and $\mathrm{CaSO} 4$. The aims this research to produce iodized salt from the field and containing $\mathrm{NaCl}$ above 94 percent which combines technology with the injection iodized in farm and Haloferax bacteria so consumed salt industry will not need washing and iodizing again. Application experiment performed 3 times which 2 replication without and with using Haloferax bacteria and additional treatment KIO3 solution concentration of 70 and 80 ppm. Results showed that best treatment was addition KIO3 $70 \mathrm{ppm}$ and treatment of bacterial Haloferax with KIO3 51,89- 56.58 ppm and $\mathrm{NaCl}$ were 94.44 to 94.95 percent. SEM EDX test results, salt cube-shaped or rectangle, treatment without addition the bacteria and the crystal morphology of appearing smaller.
\end{abstract}

Keywords: Iodized in the farm; Haloferax; $\mathrm{KIO}_{3} ; \mathrm{NaCl}$.

\section{Intoduction}

The iodized salt production process is the very simple beginning of the washing process raw materials, draining, iodized salt and printing for briquettes, cooking or drying, cooling, and packaging. Salt washing process the raw materials are beginning the process of a series of iodized salt production by using a saline solution $22-25^{0} \mathrm{Be}$ so that the levels of $\mathrm{NaCl}$ qualified SNI 4435-2010 (minimum 94.7\% NaCl). If washing solution salt concentration already exceeds $25^{\circ} \mathrm{Be}$ then most of the wash water must be removed, usually dumped in the factory environment. Discarded washing water combined with water in order to maintain the concentration of the washing water remains in $22-25^{\circ} \mathrm{Be}$. The volume of washing water discharged about $1.5 \mathrm{~m} 3$, equivalent to $500 \mathrm{~kg}$ of salt or 10 tonnes of salt-washed [1]; [2]. Every day 60-70 tons of salt wash industry raw materials. The largest component in the wastewater is $\mathrm{NaCl}$ and partly comprised of $\mathrm{MgSO}_{4}, \mathrm{MgCl}_{2}$, and $\mathrm{CaSO}_{4}$ which is an impurity of salt. Liquid waste dumped around the factory would pollute the environment because there are metal and chemical contamination.

Salt is one of the commodities that are needed by all sectors of industry. Salt consumption is included in the

\footnotetext{
* Corresponding author: nilawatibbtppi64@gmail.com
}

group of food so that is included in the priority industries in the Industrial Research and Development Agency program the Ministry of Industry. Research salt with Halophilic bacteria biotechnology has been done by previous researchers with an output that can improve the quality of the raw material salt [3]. The research has been produced by CIPPT [2]; [4-7]. All the research results obtained by raw material salt $\mathrm{NaCl}$ higher but salt consumption industry should be performed the iodized process again. The advantages of this research were obtained salt the raw materials were high quality, clean and contain $\mathrm{KIO}_{3}$ from the table crystallization in farm directly. The industry can be directly molded to be used as salt briquettes. As for the fine salt must be heating before packed. Some of the benefits in industry with iodized in farm technology, the first is to conserve water because it does not require washing and $\mathrm{NaCl}$ was already high so it does not generate liquid waste and solid waste at unit salt washing, the second is energy-efficient machine iodized and labor, and also obtaining a homogeneous $\mathrm{KIO}_{3}$ in salt consumption. In this applied research, this was not observed yet the stability $\mathrm{KIO}_{3}$ obtained. Previous on a laboratory scale research iodized salt in situ on the waste salt that has been purified obtained $\mathrm{KIO}_{3}$ salt products decreased by 0.2 to $1.3 \mathrm{ppm}$ during storage of 1-4 months [8]. Another similar research was carried out in the fields of salt iodized salt but 
using iodized spraying system and using the isolators media [9]. The difference with this research was iodized injection system in the farm enter $\mathrm{KIO}_{3}$ and bacteria Haloferax into the water $25^{\circ} \mathrm{Be}$ at the table crystallization directly.

The aim of iodization process is mixed $\mathrm{KIO}_{3}$ with saltwater evenly in order to obtain an iodized salt product which according to the requirements of SNI. Potassium iodate used recommended 40 grams diluted in water so that a concentration of $2 \%$ or $4 \%$ and used for iodized salt 1 ton [10]. Aim of this applied research was determined the effectiveness of iodized salt in the farm system to produced $\mathrm{KIO}_{3}$ homogeneous and clean salt, and do not produce liquid and solid waste in the industry.

The benefits to be obtained from this study is the product of the salt has been iodized directly from in the farm that can be directly used by the industry without having washed again so as to save water and produces no liquid waste, assuming the salt free from contamination, physical and chemical industry does not require iodized process thus saving electric energy and labor. And makes the salt industry consumption with zero-waste.

\section{Materials and Methods}

\subsection{The Locations and Time of Application Research}

Application of this research in farmer's salt fields in Pati District. Central Java Province. Indonesia. The research was conducted between June until September 2019.

\subsection{Materials and Tools}

Materials used include $\mathrm{KIO}_{3}$, distilled water, the growth cultivation medium of bacteria Haloferax, that were yeast extract, Tryptone, saline water $\left(22^{\circ} \mathrm{Be}\right)$ got from farmer's salt fields in Pati Distric., geomembrane, starter Haloferax bacteria, the chemical reagent for analysis $\mathrm{KIO}_{3}$ and $\mathrm{NaCl}$, plastic containers and sacks plastic.

The tools used were the scales, injectors $\mathrm{KIO}_{3}$, baker glass, measuring cups, Baume meter and laboratory equipment for chemical analysis. The result of the product of table salt crystallization will be tested in the laboratory include $\mathrm{KIO}_{3}$ test, $\mathrm{NaCl}$, water content and SEM EDX.

\subsection{Research Design}

Application research performed 3 times, where 2 times without using bacteria Haloferax and for the 3 times trial using bacteria Haloferax, and all treatments used KIO. $\mathrm{KIO}_{3}$ concentrations were 70 and 80 ppm [11]. Applications are done 3 times each 2 replications.

The application process research, the first step was preparing the land or tables that have been prepared for the crystallization of the salt, the second was planned geomembrane plastic, third was flowed saline water with a viscosity $25^{0}$ Be measured with Baume meter with a pond $4 \mathrm{~m} \mathrm{x} 2 \mathrm{~m}$ water height $10 \mathrm{~cm}$ simultaneously by entering $\mathrm{KIO}_{3}$ solution at concentration 70 and $80 \mathrm{ppm}$, a flow rate $80 \mathrm{ml} / \mathrm{sec}$. The crystallization process lasts up to saline water reached 29.50 Be that lasted until 4-5 days. After the salt formed carded and drained. Iodized salt consumption ready to be transported to the factory and processed further without washing, and iodized again. Salt is maintained to be free from physical and chemical contaminants.

\section{Result And Discussion}

\subsection{Levels of KIO3 in Salt crystals}

Trials 3 times in farm with 2 times without bacteria Haloferax and phase 3 trials crystallization using bacteria Haloferax and control treatment.

At the time of the crystallization process takes place was done also monitoring water quality and environmental conditions in the table crystallization, data showed that the water temperature ranges from 33$39^{\circ} \mathrm{C}, 29-33^{\circ} \mathrm{C}$ air temperature, wind speed 2.6 to 6.0 $\mathrm{m} / \mathrm{sec}$, humidity 48,8 to 70,1 percent. The results in table salt crystallization obtained salt with a rather diverse $\mathrm{KIO}_{3}$ content during the third stage of the experiment, the data as presented in Table 1.

Table 1. Trial of iodized In Farm Phase I, II and III in Salt Farmer's Field in Pati District

\begin{tabular}{|c|c|c|c|c|}
\hline Trial Phase & $\mathrm{KIO}_{3}$ concentration $(\mathrm{ppm})$ & $\mathrm{KIO} 3(\mathrm{ppm})$ & $\mathrm{NaCl}(\%)$ & Water content $(\%)$ \\
\hline & Control 1 & 2,82 & 91.16 & 3.573 \\
\hline & Control 2 & 2.24 & 92.15 & 4.646 \\
\hline $\mathrm{I}$ & $70-1$ & $<0.349$ & 82.15 & 10.041 \\
\hline & $70-2$ & $<0.35$ & 88.17 & 8.065 \\
\hline & $80-1$ & $<0.35$ & 89.35 & 8.040 \\
\hline & $80-2$ & $<0.35$ & 89.26 & 8.364 \\
\hline II & $70-1$ & 42.81 & 91.63 & 6,655 \\
\hline & $70-2$ & 48.27 & 91.42 & 3,881 \\
\hline & $80-1$ & 61.89 & 91.76 & 4.237 \\
\hline & $80-2$ & 52.37 & 90.98 & 3,810 \\
\hline
\end{tabular}




\begin{tabular}{|l|l|l|l|l|}
\hline III & $70-1$ & 56.48 & 93.37 & 5.662 \\
\hline & $70-2$ & 51.89 & 93.35 & 5.098 \\
\hline & $80-1$ & 61.45 & 94.44 & 5.811 \\
\hline & $80-2$ & 68.80 & 94.95 & 5.211 \\
\hline
\end{tabular}

Results of the Phase I application $\mathrm{KIO}_{3}$ content was still below $0.35 \mathrm{ppm}$. The reason because it allowed rainwater into the water to overflow in the farm, but the process is waiting to happen salt until the brine reached $29.5^{\circ} \mathrm{Be}$. For the phase II trial, obtained his $\mathrm{KIO}_{3}$ levels according to the expected value varies, with the result 70 contains $\mathrm{KIO}_{3} 42.81 \mathrm{ppm}$ and $47.27 \mathrm{ppm}, 80 \mathrm{ppm}$ while containing $\mathrm{KIO}_{3}$ at 52.37 and 61.89 ppm. Phase III treatment trial using bacteria Haloferax then the resulting value $\mathrm{KIO}_{3}$ to increase the concentration of 70 ppm in value by 51.89 and 56.48 being the addition $\mathrm{KIO}_{3}$ got 61.45 to $68.80 \mathrm{ppm}$ to $80 \mathrm{ppm}$. SNI requirements iodized salt consumption was at least 30 ppm. $\mathrm{KIO}_{3}$ user so that as much as $70 \mathrm{ppm}$ in crystallization table already applied. For the control treatment, there also $\mathrm{KIO}_{3}$ content 2.24 to 2.82 because in the seawater the $\mathrm{KIO}_{3}$ content is also very small quantities. Compounds $\mathrm{Fe}^{2+}$ and $\mathrm{Cu}^{+}$(contained in salt) $\mathrm{KIO}_{3}$ in salt were able to decompose into $\mathrm{I}_{2}$. Thus, any amounts of reducing agent contained in the salts the greater the number of $\mathrm{KIO}_{3}$ that will decompose and disappear as $\mathrm{I}_{2}(\mathrm{~g})[2]$.

\subsection{Levels of $\mathrm{NaCl}$}

The result was the control treatment containing $\mathrm{NaCl}$ content of 91.16 to 92.15 percent. In the second stage of Phase, I containing $\mathrm{NaCl}$ decreased from 82.15 to 89.28 percent, from 90.88 to 91.76 percent in value phase II and phase III of its value from 93.93 to 94.95 percent. The high $\mathrm{NaCl}$ in the treatment of bacterial Haloferax addition, due to these bacteria can degrade the compounds of impurities contained in the brine solution as $\mathrm{Mg}$ and $\mathrm{Ca}$ compounds, such research has been done that Haloferax that bacteria can improve the quality and quantity of salt [12].

The Haloferax bacterial cells are templates in the formation of halite/crystal $\mathrm{NaCl}$ and organic compounds produced by haloferax bacteria also have an influence on the shape and formation of formed salt crystals. [13].

\subsection{Results Analysis of SEM EDX}

SEM is Scanning Electron Microscopy and EDX is Energy Dispersive X-Ray analysis results of experiments in the fields for the control treatment and the addition of bacteria Haloferax treatment show similarity. Form Haloferax bacterial cell is a template in the formation of halite or $\mathrm{NaCl}$ crystals and organic compounds produced by bacteria haloferax also have an influence on the shape and the formation of salt crystals formed [13]. Besides the secretions of organic substances from bacteria Haloferax such as glycine, betaine, and polysaccharides also influence the quality of the resulting salt crystals [3]. There appears to be a similar shape of salt crystals that tendency cube-shaped box or a rectangle, but for the addition of the crystal morphology of the bacteria appear smaller pieces.

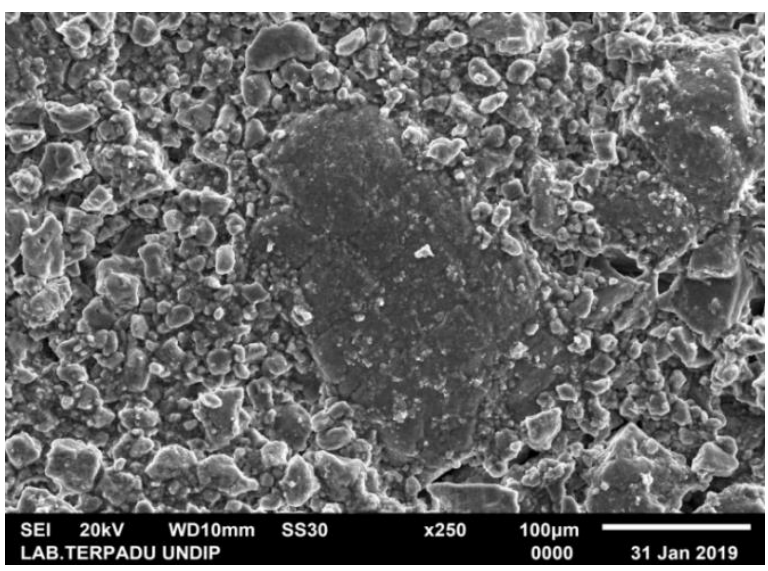

Fig. 1. Results of Test SEM EDX Iodized Salt Crystal Without Haloferax Bacteria Treatment Enlargement 250x

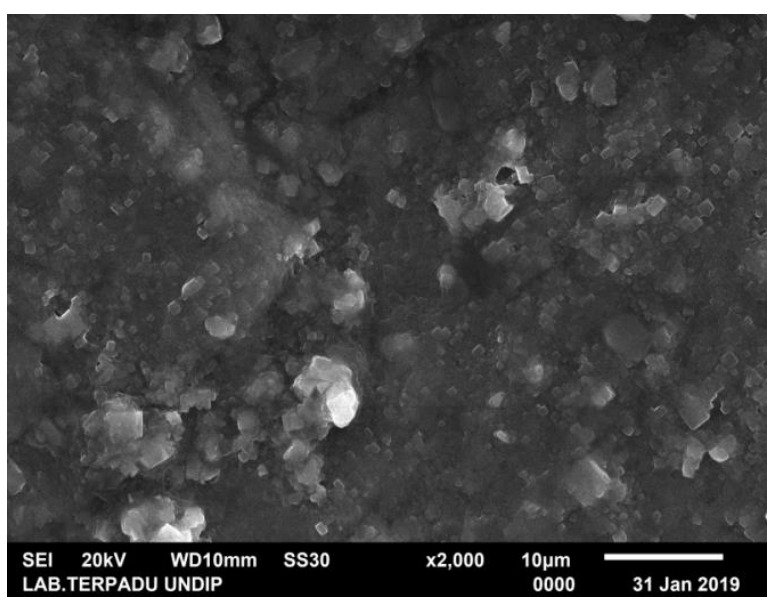

Fig. 2. Results of Test SEM EDX Iodized Salt Crystal Without Haloferax Bacteria Treatment Enlargement 2000x

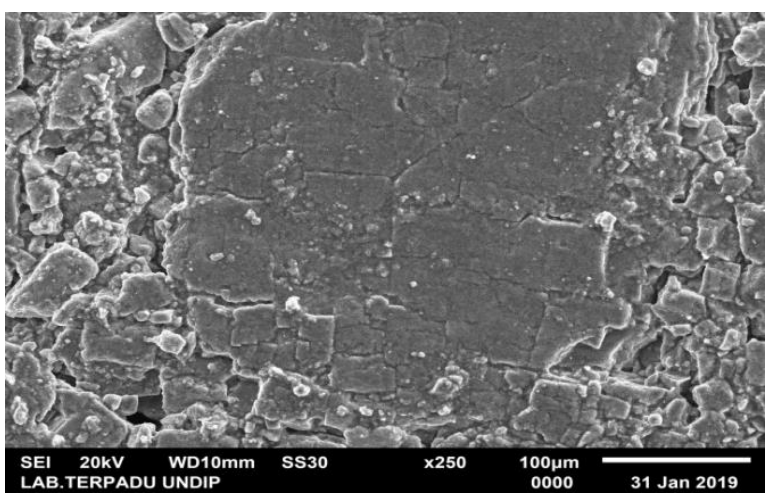

Fig. 3. Results of Test SEM EDX Iodized Salt Crystal with Haloferax Bacteria Treatment Enlargement 250x 


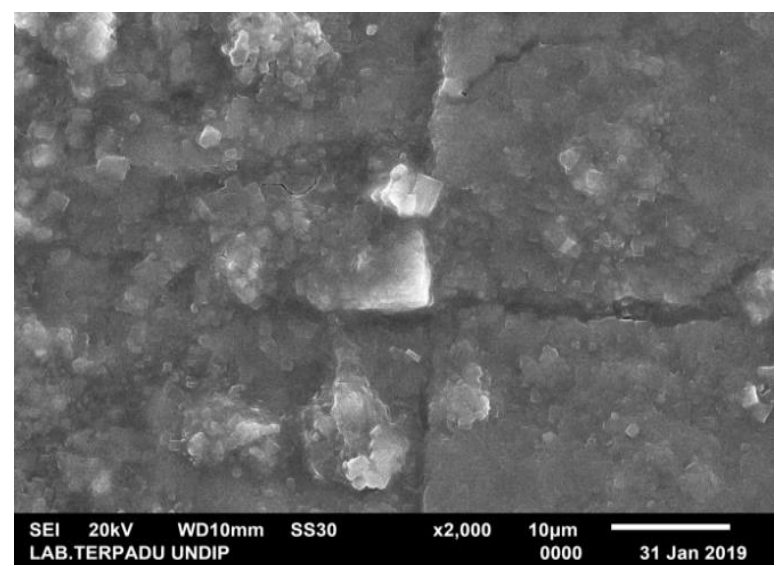

Fig. 4. Results of Test SEM EDX Iodized Salt Crystal with Haloferax Bacteria Treatment Enlargement 2000x

\section{Summary}

The results of applications research of salt iodized in farm gave $\mathrm{KIO}_{3}$ value of the first phase is still below 0 , while the second phase $\mathrm{KIO}_{3}$ that 70 and $80 \mathrm{ppm}$, the results thereof containing $\mathrm{KIO} 3$ were 42.81 to 61.89 ppm, then the third stage used Haloferax bacteria gave the resulting value of $\mathrm{KIO}_{3}$ were 51.89 to $68.80 \mathrm{ppm}$. Phase I trials contain $\mathrm{NaCl}$ obtained by 82.15 to 91.46 percent, phase II and phase III from 90.92 to 92.15 91.63 to 94.44 percent.

SEM EDX test results tendency the form of salt crystals is a cube-shaped box or a rectangle, but for the control of the crystal, morphology appears smaller pieces.

Result of application iodized salt in the farm with giving concentration $\mathrm{KIO}_{3} 70$ ppm treatment was able to generate content $\mathrm{KIO}_{3}$ above 30 ppm in a salt crystal.

This research support funded by the Center of Industrial Pollution Prevention Technology(CIPPT), Ministry of Industry. Further thanks to the CV. Garam Mulia who has given the opportunity of application research is conducted are located at Pati District, Central Java Province.

\section{References}

1. Nilawati, JMP Book on Iodized Salt Industry, Rafi Saran Perkasaa Semarang (2014)

2. Nilawati, Marihati, R.A. Malik, The ability of Haloferax spp bacteria to increase the purity of $\mathrm{NaCl}$ in the crystallization process, Jurnal Riset Teknologi Pencegahan Pencemaran Industri 8, 92104 (2017)

3. A. Oren, Thoughts in the "Missing Link" Between Biology and Solar Saltworks Salt Quality. Global Nest Journal 12 (4), 417-425 (2010)

4. Marihati, Muryati, D.K. Hemawan, Rahmanto, The Isolation of Halophilic Bacteria for Salt Purification, Laporan Teknis BBTPPI Semarang, (2011)

5. N. Marihati, N. Harihastuti, Asyari, Suwito, Muryati, Nilawati, D.W.K. Hermawan, M.S.E.
Nugroho, Winarno, F.A. Hidayat, Nelfilviyanti, Rahayu, Pilot Project Quality \& Productivity Improvement And Salt People With cultivation salt Salt House System Based Biomanajemen Haloferax spp bacteria and Artemia Salina. Technical Report. Center for Industrial Pollution Prevention Technology. Policy Assessment Agency, Climate and Industrial Quality (2012)

6. Marihati, Application of SNI Products in Iodized Salt Small and Medium Industries, Rafi Sarana Perkasa Semarang (2013)

7. Marihati, N. Harihastuti, Muryati, Nilawati, S. Eddy, Herman, W. Danny, The use of Haloferax spp as a Biocatalyst to Improve the Quality and Productivity of $\mathrm{NaCl}$ Salt in the Crystallization Table, Jurnal Riset Industri 8(3), 191-196 (2014)

8. Nilawati, Marihati, Purification and Iodization of In Situ Processing of Blotong Solid Waste into Consumption Salt in Iodized Salt Industry, Jurnal Biopropal Industri 6, 2 (2015)

9. Sudarto, Iodized Salt Production Process in Salting Land on Crystallization Table with Isolator Media, Kementerian Hukum dan Hak Asasi Manusia, Republik Indinesia (2014)

10. Marihati, Nilawati, Internal Management and Optimization of the Production Process in Iodized Salt IKM towards Obtaining SNI Products Certificate. Proceedings of the National Seminar on Local Food, Business, Eco-Industry, Program Studi Teknologi Pangan Fakultas Teknik Universitas PGRI Semarang. (2015)

11. BBTPPI, Consumption of Environmentally Friendly Consumption of Salt Using a Combination of Haloferax Spp Bacteria and Iodization of Flow Injectors in Farm, Balai Besar Teknologi Pencegahan Pencemaran Industri Badan Penelitian dan Pengembangan Industri, Kementerian Perindustrian RI (2018)

12. N. Saksono, Study of the Effect of Salt Washing Process on Consumption and Stability of Iodized Salt Consumption, Makara Technology 6, 1 (2002)

13.L.A. Cortez, L.J. Ochoa, The biological significance of halobacteria on nucleation andsodium chloride growth, Elsevier crystal science BV, Studies in Surface Science and Catalysis 120, 903-922 (1998) 